This is an author produced version of a paper published in Biomass and Bioenergy. This paper has been peer-reviewed and is proof-corrected, but does not include the journal pagination.

Citation for the published paper:

Lindroos, O. (2011) Residential use of firewood in Northern Sweden and its influence on forest biomass resources. Biomass and Bioenergy.

Volume: 35 Number: 1, pp 385-390.

http://dx.doi.org/10.1016/j.biombioe.2010.08.054

Access to the published version may require journal subscription.

Published with permission from: Elsevier

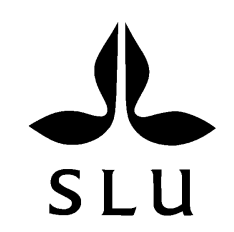

Epsilon Open Archive http://epsilon.slu.se 


\title{
Residential use of firewood in Northern Sweden and its influence on forest biomass resources
}

\author{
Ola Lindroos \\ Dept of Forest Resource Management, Swedish University of Agricultural Sciences, Sweden \\ Published 2011 in Biomass and Bioenergy 35(1), 385-390. \\ The original publication is available at www.elsevier.com, doi:10.1016/j.biombioe.2010.08.054.
}

\begin{abstract}
Firewood is society's oldest source of household energy and is still extensively used around the world. However, little is known about firewood usage in technologically advanced countries with high energy consumption. Some key issues include quantities of firewood currently used and future trends, as well as the influence of this usage on available biomass resources. This study addresses those issues through a postal questionnaire to 1500 of the firewood using households in a region in Northern Sweden. One-third of households produced 11-20 solid m3 of firewood per year. Three-fourths expected their production to be unchanged or increase during the coming five years. A large proportion of young producers indicated long-term continuation of firewood usage. Half (53\%) of the firewood producing households owned forest and thereby had free access to wood. Produced firewood volume corresponded to $4-8 \%$ of the region's roundwood volume harvested for industrial purposes. The use of firewood is suggested to influence decisions of private forest owners about management and harvest of forest biomass, and, thus, affect supply for bioenergy and other uses. With further incorporation of firewood usage into forest biomass management regimes, larger biomass quantities are likely to be available for industrial uses.
\end{abstract}

Keywords: Biomass resources, fuelwood, forestry, public opinion, resource potential.

\section{Introduction}

Firewood (defined here as solid wood, mainly from the tree trunk) is society's oldest source of household energy and is still used around the globe [1], even in technologically advanced countries with high energy consumption [2, 3]. This paper (mainly considers such countries' firewood use (i.e. for heating purposes but not for cooking) for which the firewood's share of the total energy consumption might be generally modest (e.g. 1.4\% of Sweden's total energy consumption [4]). Nevertheless, it contributes considerably within of heating of detached houses (e.g. $25.0 \%$ of their consumed heating energy in Sweden [5].

The use of firewood is a function of a need for heating (because of the climate) and (access of private persons to firewood [6-8]. The access can be determined both by population density (urban-rural gradient (e.g. [7])) and by forest ownership [8]. The volumes used depend on conversion efficiency [9] and heating need, the latter being a function of climate [6, 10], building size [10] and construction (insulation) standard [5] Consequently, that the area of forests that are private owned or accessible and that the climate is temperate are likely to promote firewood use.

From the individual's perspective, firewood usage is normally prompted by possession of a residence that has a firewood-based heating system, and the firewood needed is often produced by the consumer on leisure time basis (e.g. [11-13]). In terms of the use of forest biomass resources, the production of firewood is considered to be more important than the consumption. However, the self-sufficient aimed production can be considered to be similar to the consumption and, therefore, the term 'usage' of firewood is used when both production and consumption are being addressed. Motives for the usage include economic and to a certain extent recreational factors [13, 14]. The quantity of firewood annually used per household is generally small; i.e. well below $20 \mathrm{~m}^{3}$ of solid wood [6, 9, 13-15]. However, the number of firewood using households is large; i.e about one-fourth of all households in Australia [12] and the U.S [6] use firewood. Hence, the total quantity consumed in technologically advanced countries is considerable. Firewood's importance is clear when comparing the volumes with other tradi- 
tional use of forest biomass; i.e. volumes delivered to lumber and pulp industry (Table 1).

That firewood usage needs to be included in estimations of biomass potentials has been recognized in both global [16] and national assessments [17]. Energy crises generally increase the interest in firewood usage (c.f. [6]). Consequently, the scientific interest is normally connected to those fluctuations, with the extensive monitoring of firewood assets in the 1980s (e.g. [6, 7, 10]) being the result of the oil crisis of the 1970s. In the new millennium, the interest has increased due to a growing focus on bioenergy. Moreover, household interest in using firewood has revived. The use is likely to increase, due to rising costs of alternative sources of energy for heating (e.g. electricity and petroleum products) and there is increasing interest in the use of all sustainable and environmentally friendly heating systems. In Finland, for example, 15000 households planned to start using firewood and 200000 households planned to increase their firewood usage during 2002-2003 [18]. In Lithuania, firewood usage has increased by 500 percent in the last ten years [19]. However, contemporary studies on firewood usage are rare.

There are many challenges in the estimating of firewood usage due to the small scale, selfsufficiency use in conjunction with confusing nomenclature and quantity measures [22]. Therefore, existing national estimations can generally be considered as rough indications. In Sweden, for instance, there are two national estimations. One is focused on the energy consumption in detached houses [5] and one is based on harvested forest volumes [4]. For 2005, their estimations were 4.8 and 5.9 million $\mathrm{m}^{3}$, respectively, when using the conversion factors presented in 2.2. Although these estimations are of similar magnitude, the relative discrepancy is large and consequently, there is a need for further empirical data. Additionally, future trends in firewood usage and the influence of this usage on forest biomass resources need to be addressed in the new light of rapidly escalating industrial demand.

The objective of the conducted study was therefore to analyse small-scale firewood production in general and the demographical aspects in particular. This was done through a postal questionnaire to a random sample of the households able to heat their houses with firewood in a region in Northern Sweden.

\section{Material and methods}

\subsection{Survey}

The study targeted the Umeå region, consisting of a medium-sized Swedish town surrounded by five municipalities (Bjurholm, Nordmaling, Robertsfors, Vindeln and Vännäs). In each of these rural municipalities there is a commercial and administrative centre, but they are mainly characterized by small, scattered villages and forested land. The total number of inhabitants in the region was 142000,71000 of whom resided in the town of Umeå, and the land area was $9372 \mathrm{~km}^{2}$ [23]. The region was considered to represent typical Swedish conditions.

Chimney sweeping was compulsory by law and registers were held by companies with geographically distributed responsibilities for the sweeping. The registers in the region were searched for households with firewood heating systems, and the 11498 households found were used as sample frame. Simple random sampling was used to select 1500 households, to which a questionnaire was mailed in April 2006. The sample did not significantly differ from the sample frame with respect to either municipality or stove type proportions $\left(\chi^{2}=20.67\right.$, d.f. $=$ $23, \mathrm{p}=0.60)$. Fourteen households $(1 \%)$ in the sample no longer existed and thus the 904 replies corresponded to a reply frequency of $61 \%$. Compared to the sample, reply proportions were independent of municipality and stove type $\left(\chi^{2}=14.10\right.$, d.f. $=15$, $\mathrm{p}=0.52)$, indicating that responding and nonresponding households did not differ significantly in these respects.

The questionnaire started with questions as to whether firewood was used by the household and whether anyone in the household was involved in firewood production. The following section concerned questions about the specific category and age of equipment used in firewood production. The second section of the questionnaire concerned the quantities of firewood produced, distributed into five volume categories, and the amount of labor invested. Consumption was not addressed. The last section of the survey included miscellaneous questions regarding inter alia, the ownership of forest land ( $>1$ ha) by members of the household. For a more comprehensive description of the study, readers are directed to Moe [24]. Some of the survey results have previously been reported internationally [25] in terms of the survey's forest owning households' firewood processing and related accidents. In this paper, however, a thorough analysis of the use of firewood is presented. 


\subsection{Conversion factors}

To suit the large variation of firewood measures (c.f. [22]), volumes were possible to quantify in three different measures in the survey. Differences between one cubic meter of stacked, piled and solid wood are illustrated in Fig. 1. Solid wood is used in this paper, with $1 \mathrm{~m}^{3}$ corresponding to 1.5 and 2.0 $\mathrm{m}^{3}$ of stacked and piled firewood, respectively. Given that broad leaf species are most commonly used (e.g. [14]) an estimated basic density for firewood of $452 \mathrm{~kg} \mathrm{~m}^{-3}$ comprised mean basic densities of birch (Betula ssp.) of $475 \mathrm{~kg} \mathrm{~m}^{-3}$, Scots pine (Pinus sylvestris) of $413 \mathrm{~kg} \mathrm{~m}^{-3}$ and Norway spruce (Picea abies) of $385 \mathrm{~kg} \mathrm{~m}^{-3}$ [26] with a weight relation of 14:3:3. Normal moisture content for air dried firewood is $20-30 \%$ [27]. The net calorific value was $19.3 \mathrm{MJ} \mathrm{kg}^{-1}$ of dry matter [28].

\section{Results}

Out of the 904 replies, 710 households (78.5\%) used firewood. In total, 608 households (67.1\%) produced firewood, of which 319 (52\%) also owned forest land ( $>1 \mathrm{ha})$. Some households (2.3\%) produced firewood although they did not use it themselves.

The largest proportion of households (33.9\%) produced between 11-20 solid $\mathrm{m}^{3}$ of firewood per year (Fig. 2). Most respondents (61\%) reported their firewood production in $\mathrm{m}^{3}$ stacked wood, while $27 \%$ reported in $\mathrm{m}^{3}$ of piled and $10 \%$ reported in $\mathrm{m}^{3}$ of solid wood. Deduction based on results to the whole region suggest that the total volume is between 66500 and at least 108700 solid $\mathrm{m}^{3}$ annually, when calculating with class bottom and top, respectively. If setting the $>20 \mathrm{~m}^{3}$ class maximum value to $40 \mathrm{~m}^{3}$, the upper limit of the total volume increased to $136500 \mathrm{~m}^{3}$.

Most households (66.8\%) stated that their firewood production was not expected to change during the coming five years (Fig. 3). Decreased production was anticipated by $22.6 \%$ of households whereas increased production was anticipated by $10.6 \%$. Expected increases were most frequently reported by households producing the least quantity of firewood and least frequently reported by households producing the largest quantity of firewood. Moreover, households producing the largest quantity of firewood reported an expected decrease in production, but the differences between production classes were small (spread 7.3 percent units).

All age classes were represented in the firewood production, with $20 \%$ in age classes younger than 40 years, $44 \%$ in classes between 40 and 60 years and $36 \%$ in classes of 60 years or older. Production of the largest quantities of firewood was more common within the highest household age classes (Table 2). The distribution of production classes was similar over age classes, with 22 percent units being the largest spread (production class 1-5 $\mathrm{m}^{3}$ ).

\section{DISCUSSION}

\subsection{Biomass used}

Despite the relatively small volume of firewood produced per household, the estimated total of $66500-136500 \mathrm{~m}^{3}$ corresponded to $6.8-14.2 \%$ of the volume delivered to saw and pulp mills from the privately owned forest properties in the region [29]. When including also the other ownership types, the firewood volume corresponded to $3.6-7.6 \%$ of the region's total volume delivered to industry [29]. Compared to international standards, the proportion is low (Table 1), which is probably because Sweden in these terms is a country with low population density and large forest assets that are intensely used for industrial purposes. Such an explanation holds also for the national comparison with Gotland (34\% [30]), which has fewer forest assets and less industrial activity than the national average [4].

The current study can be used to infer Swedish firewood usage in three different ways. When applying the distribution found between firewood and volumes delivered to industries from all owner categories on a national level (56.1 million $\mathrm{m}^{3}$ in the year 2006 [4]), the volume sums to between 2.0 and 4.3 million $\mathrm{m}^{3}$. When applying the regional usage per household with firewood heating systems to the nation's amount of such households ( $\mathrm{N}=600000$ [31]), the volume sums to between 3.5 and 7.1 million $\mathrm{m}^{3}$. When applying the firewood usage per capita in the region on a national level (9.1 million inhabitants [32]), the volume sums to between 4.3 and 8.7 million $\mathrm{m}^{3}$. Out of the three estimations, only the first does not include current estimations $[4,5]$ within its interval.

As stated in the introduction, firewood use for heating is prompted by climatic factors. However, colder climate does not necessarily results in more frequent use of firewood or higher consumption. An example of the lack of relations can be deduced from the study. No information is available on the number of households in the Umeå region, but if the size of households are 2, 3 or 4 persons, the proportions of households using firewood would be 13, 19 and $25 \%$, respectively. The equivalent proportions of households that produced firewood were 10, 16 and $22 \%$, respectively. These are lower or corresponds to the proportion of firewood using households in the considerably warmer countries of, 23\% in Australia [12] and 25\% in Southeastern US [11]. 
The findings are most likely explained by differences in heating needs and how they are met. With increased need for heating, firewood-based central heating systems are probably more common than firewood stoves and open fireplaces. Additionally, with compulsory heating needs for several months per year, alternative heating alternatives are likely to be considered.

\subsection{Future trends}

As mentioned in the introduction, the use of firewood is not likely to decrease in the near future, due to rising costs of alternative heating resources, e.g. electricity and petroleum products. This assumption conforms to contemporary findings from Northern Europe [10, 19] and was partly confirmed in the study. Two-thirds of the households anticipated no change in firewood usage. Of the other households, more than one-fifth anticipated usage decreases and especially among households using large volumes. Interpretations should, however, be made cautiously since quantities of neither anticipated increases nor decreases were known. Moreover, a possible increase in the number of firewood using households in the future, (c.f. $[9,10]$ ) was not accounted for. The overall impression is therefore that no large changes will occur in firewood usage. Besides the study's short-term prediction (5 yrs), a long-term continuation of firewood usage was indicated by a large proportion of young users who most likely will find it profitable to use firewood also in the future.

\subsection{Firewood's influence on industrial biomass}

When calculating potentials of forest biomass, the total quantity needs to be decreased according to a certain number of restrictions to mirror a realistic usage potential. Restrictions due to difficult terrain and technological limitations are normally considered, as well as current use of the biomass. Less often considered are possible restrictions caused by ownership. In Sweden, private individuals own half of the forest land [4] and owners decide if and what to harvest. Whether they are willing to allow usage of currently unused biomass potentials is seldom considered, probably due to an assumption that they follow the laws of economic rationality. Forest owners have, however, repeatedly been found to have other objectives than economy with their forest ownership (e.g. [19, 33]), and the income only slightly influences the decision to sell biomass or not [34]. Firewood's importance for forest owners has, on the other hand, been manifested previously $[19,33,35]$ and can also be deduced from this study. The results indicate that circa 4000 forest owning households produce firewood in a region with 6600 family forestry holdings (with $>1$ ha forest) [36]. With such a large proportion of family forests at least partly used to meeting firewood needs, these needs are likely to influence forest management (biomass production) practices. It is in fact often likely to be the main driver of forestry activities. An example is that as many as $30 \%$ of the family forest owners cite firewood requirements as being an important factor in their decisions to perform pre-commercial thinning (PCT) and 69\% take firewood from PCT [37].

In a conflict situation it can be strongly argued that activities ensuring biomass production for domestic needs will override production for industrial purposes, since the need for heating is likely to be a much stronger incentive for the activity than good forest management and long-term economic benefits. However, with only small volumes needed annually for a given household's domestic heating, such a production dichotomy will seldom occur.

If a conflict situation should occur, what segments of the woody biomass would then be affected? Generally, small diameter roundwood with high calorific value is wanted for firewood. Thus, there is already a quiet competition and balance between the use of pulp wood and firewood [6]. Even smaller diameter of broad leaf tree species is currently considered for industrial bioenergy purposes [38], which would possibly interfere with firewood usage.

\subsection{Industrial biomass' influence on firewood}

Although there are more objectives than economic matters related to forest owning (e.g. [33]) and firewood production (e.g. [14, 35]), better payment for forest biomass is likely to increase the quantities allowed to be harvested. Concerns related to the harvest are, however, important to deal with adequately [34]. Given the firewood's expected outranking of industry deliverances, price increments are not likely to severely affect the forest owners' firewood usage. However, the number of firewood producing households that owned forest was similar to the number that did not own forest in the study. Households that do not own forest are, thus, not granted access to the required biomass. Firewood is not only obtained from forestland [6]; nevertheless, households without forests might experience restrictions on their use of firewood in a situation with increased competition for the forest biomass.

Another aspect of the equal distribution between households with and without forest ownership indicates that firewood usage includes a considerably larger body than family forestry alone and that firewood usage has a considerable impact on a rural development level. Whether that impact will complement or compete with an intention for increased use of rural areas' forest biomass is as yet unknown. 


\subsection{Study limitations}

The results of this article are likely to be particularly relevant to the Nordic countries, and also to other regions where firewood is used and produced similarly as in the present study, such as large portions of Europe, North America and Australia.

All retrospective questionnaire and interview studies are subject to biases depending on various factors including memory, willingness to reply, socio-economic factors and misunderstandings (e.g. [39]). Compared to a previous Swedish study [5], the current study included more households. On the other hand, it was restricted to a limited region of the country and the two studies can thus be considered complementing each others' validity.

When comparing studies, there is a risk of confounding firewood usage with socio-economic and demographic factors. When such factors are considered, usage is most commonly related to number of households. Even though household often is a natural unit in studies, it is difficult to define and quantify; moreover, it varies between countries. Sometimes, the usage has been reported per capita (e.g. [40]), which gives better possibilities to compare. However, many firewood usage features are more related to households than to individuals. Thus, the household relation was used in the current study due to practical reasons (i.e. available registers over households).

An even larger obstacle in comparisons are the multitude of quantitative measures used (c.f. Fig. 1 and [22]) and, additionally, the wood's heterogeneity in terms of and calorific value per quantity unit. The many and often abstract quantity measures might explain why firewood users previously have been found to overestimate their consumption [6]. As with other comparisons of energy intended resources, the unit most plausible for comparisons would therefore be energy based. However, such a unit is not easily defined for firewood, and moreover, it is seldom the one that respondents understand or can estimate. Nevertheless, it is strongly recommended that suitable conversion values are provided to enable meaningful comparisons.

\section{Conclusion}

Firewood constitutes a considerable part of the forest biomass currently used, and there are no indications of a decline in the near future. The use of firewood is suggested to influence forest owners' decisions on management and harvest of forest biomass, and thus affect supply for bioenergy and other uses. This has hitherto only marginally been considered, but is considered to be an increasingly important aspect in a market with a rapidly escalating demand for forest biomass. With further recognition of firewood's importance for forest owners and with its incorporation into forest biomass management regimes, larger biomass quantities are likely to be available for industrial uses.

\section{Acknowledgements}

This study was conducted within the FOR programme, which addresses the self-employed family forestry's working conditions. The work was financially supported by the Faculty of Forest Sciences at the Swedish University of Agricultural Sciences, the SLO foundation's grants SLO-918 and the Gunnar and Birgitta Nordins foundation's grant N-84. Thanks are also due to Daniel Moe for assistance with the survey compilation and to Steve Scott Robson for revising the English.

\section{References}

[1] Trends in Forest Products 1961-2003. Rome: Food and Agriculture Organization of the United Nations (FAO); 2005.

[2] Warsco K. Conventional fuel displacement by residential wood use. Forest Products Journal 1994;44:68-74.

[3] Röser D, Asikainen A, Gjølsjø S, Jaskelevicius B, Johansson D, Jyhlä P, et al. Wood Fuel Resources and Bottlenecks of Utilization in Baltic and Nordic countries. Joensuu, Finland: Finnish Forest Research Institute; 2003.

[4] Statistical Yearbook of Forestry 2007. Jönköping, Sweden: National Board of Forestry; 2007.

[5] Energy statistics for one- and two-dwelling buildings in 2006. Stockholm: Statistics Sweden; 2007.

[6] Skog KE, Watterson IA. Residential fuelwood use in the United States. Journal of Forestry 1984;82:742-47.

[7] Lipfert FW, Dungan JL. Residential firewood use in the United States. Science 1983;219:1425-27.

[8] Turker MF, Kaygusuz K. Investigation of the variables effects on fuelwood consumption as an energy source in forest villages of Turkey. Energy Conversion and Management 2001;42:1215-27.

[9] Force JE. Residential wood energy use in Idaho. Forest Products Journal 1989;39:25-29.

[10] Hardie IW, Hassan AA. An econometric analysis of residential demand for fuelwood in the United States, 1980-1981. Forest Science 1986;32:1001-15.

[11] Christiansen EH, Larsen MD, Bliss JC, Nepal SK, Rejda K, Brooks RT. Residential fuelwood consumption in the Southeastern U.S. Biomass and Bioenergy 1993;5:489-93.

[12] Driscoll D, Milkovits G, Freudenberger D. Impact and use of firewood in Australia. Canberra: CSIRO Sustainable Ecosystems; 2000.

[13] Force JE. Fuelwood in Idaho: Implications for forest management. Journal of Forestry 1985;83:3639. 
[14] Isachsen O. Trade with and use of firewood. Ås, Norway: Norwegian Forest Research Institute; 1984.

[15] Sundin T. Fuelwood as a source of energy in private forestry - the situation in 1979 and future potentials. Garpenberg: Department of Operational Efficiency, Swedish University of Agricultural Sciences; 1982.

[16] Parikka M. Global biomass fuel resources. Biomass and Bioenergy 2004;27:613-20.

[17] Hagström P. Biomass potentials for heat, electricity and vehicle fuel in Sweden. Volume I. Faculty of Natural Resources and Agricultural Sciences. Uppsala: Swedish University of Agricultural Sciences; 2006.

[18] Tuomi S. Fuelwood usage is increasing in detached houses in Finland. Finnish Work Efficiency Institute (TTS) 2003;Teho No. 1:24-26.

[19] Mizaraite D, Mizaras S, Sadauskiene L. Wood fuel supply, costs and home consumption in Lithuania. Biomass and Bioenergy 2007;31:739-46.

[20] Nord-Larsen T, Talbot B. Assessment of forestfuel resources in Denmark: technical and economic availability. Biomass and Bioenergy 2004;27:97-109.

[21] Memento AFOCEL 2006. Nangis, France: AFOCEL; 2006

[22] Marsinko APC, Phillips DR, Cordell HK. Determining residential firewood consumption. Environmental Management 1984;8:359-66.

[23] Facts about Västerbotten 2006. Umeå: Västerbotten County Administrative Board and Västerbotten County Council; 2006.

[24] Moe D. Residental firewood production in Sweden - a case study in the Umeå region. Umeå: Department of Forest Resource Management, Swedish University of Agricultural Sciences; 2007.

[25] Lindroos O, Wilhelmson Aspman E, Lidestav G, Neely G. Accidents in family forestry's firewood production. Accident Analysis and Prevention (2008); 40:877-886.

[26] Repola J. Models for vertical wood density of Scots pine, Norway spruce and birch stems, and their application to determine average wood density. Silva Fennica 2006;40:673-85.

[27] Liss JE. Brännved - torknings- och lagringsförsök [Firewood - drying and storage experiments]. Garpenberg, Sweden: Department of Forestry and Wood Technology, Dalarna University; 2000.

[28] Lehtikangas P. Lagringshandbok för trädbränslen [Storage handbook for tree fuels]. 2nd ed.
Uppsala: Swedish University of Agricultural Sciences; 1999.

[29] Avverkning inom samtliga ägarkategorier [Cutting within all ownership categories]. National Board of Forestry, Västerbotten 2007; 2007. http://www.skogsstyrelsen.se/episerver4/templates/SN ormalPage. aspx?id=12260.

[30] Sundblad K. Sysselsättning och avverkning inom skogsbruket på Gotland [Occupation and cutting in forestry on Gotland]. Visby, Sweden: County Board of Gotland; 2000.

[31] Att elda med ved [To burn firewood]. Sveriges skorstenfejarmästares riksförbund; 2008, http://www.skorstensfejare.se/pub26.asp.

[32] Statistical Yearbook of Sweden 2008. Stockholm: Statistics Sweden; 2008.

[33] Berlin C, Lidestav G, Holm S. Values placed on forest property benefits by Swedish NIPF owners: Differences between members in forest owner associations and non-members. Small-Scale Forestry 2006;5:83-96.

[34] Bohlin F, Roos A. Wood fuel supply as a function of forest owner preferences and management styles. Biomass and Bioenergy 2002;22:237-49.

[35] Mizaraite D, Mizaras S. The formation of smallscale forestry in countries with economies in transition: Observations from Lithuania. Small-Scale Forestry 2005;4:437-50.

[36] Almqvist B. Data extraction from the forest holding database Kotten - personal communication. Swedish Forest Agency, Bjurholm; 2006.

[37] Fällman K. Aspects of precommercial thinning private forest owners' attitudes and alternative practices. Department of Silviculture. Umeå: Swedish University of Agricultural Sciences; 2005.

[38] Bergström D, Bergsten U, Nordfjell T, Lundmark T. Simulation of thinning systems and their time requirements for young forests. Silva Fennica 2007;41:137-47.

[39] Niemi I. Systematic error in behavioural measurement: comparing results from interview and time budget studies. Social Indicators Research 1993;30:229-44.

[40] Misra MK, Sahu NC, Govind Rao B, Nisanka SK. Domestic fuel energy consumption in an Indian urban ecosystem. Biomass and Bioenergy 1995;9:47386. 


\section{Tables and Figures}

Table 1 - Total volume of roundwood annual harvested and its proportion of firewood

\begin{tabular}{lrcc}
\hline Country & $\begin{array}{r}\text { Volume } \\
\left(10^{6} \mathrm{~m}^{3}\right)\end{array}$ & $\begin{array}{c}\text { Firewood } \\
(\%)\end{array}$ & Source \\
\hline Sweden & 62.0 & 10 & {$[4]$} \\
Finland & 51.6 & 9 & {$[4]$} \\
Denmark & 2.0 & 20 & {$[20]$} \\
Lithuania & 6.7 & 27 & {$[19]$} \\
France & 59.4 & 40 & {$[21]$} \\
US & 89.1 & 23 & {$[6]$} \\
Globally & 3271.0 & 55 & {$[16]$} \\
\hline
\end{tabular}

Table 2 - The distribution of annual firewood production $\left(\mathrm{m}^{3}\right.$ solid wood) within classes of the households' work time weighted mean age (\%)

\begin{tabular}{lcccccc}
\hline & \multicolumn{7}{c}{ Age class (years) } \\
\cline { 2 - 7 } $\mathrm{m}^{3}$ & $\begin{array}{c}0-29 \\
(n=10)\end{array}$ & $\begin{array}{c}30-39 \\
(n=101)\end{array}$ & $\begin{array}{c}40-49 \\
(n=121)\end{array}$ & $\begin{array}{c}50-59 \\
(n=128)\end{array}$ & $\begin{array}{c}60-69 \\
(n=143)\end{array}$ & $\begin{array}{c}>69 \\
(n=60)\end{array}$ \\
\hline$<1$ & 0 & 3 & 5 & 5 & 1 & 2 \\
$1-5$ & 20 & 37 & 22 & 24 & 24 & 15 \\
$6-10$ & 20 & 14 & 21 & 23 & 19 & 18 \\
$11-20$ & 40 & 34 & 34 & 28 & 34 & 42 \\
$>20$ & 20 & 13 & 17 & 20 & 22 & 23 \\
\hline
\end{tabular}
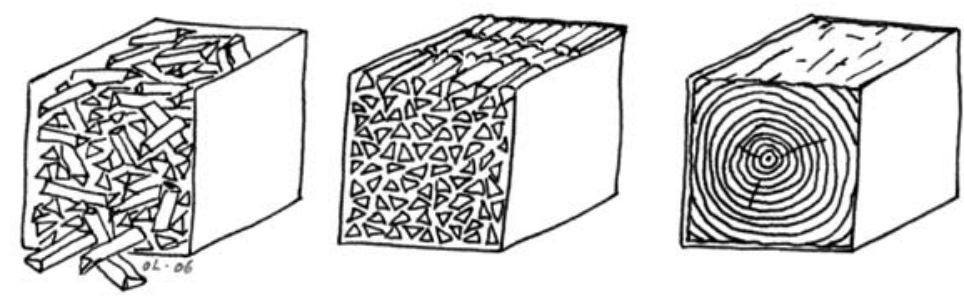

Fig. 1 - Schematic illustration of the differences between (from left) one cubic meter of piled, stacked and solid wood. 


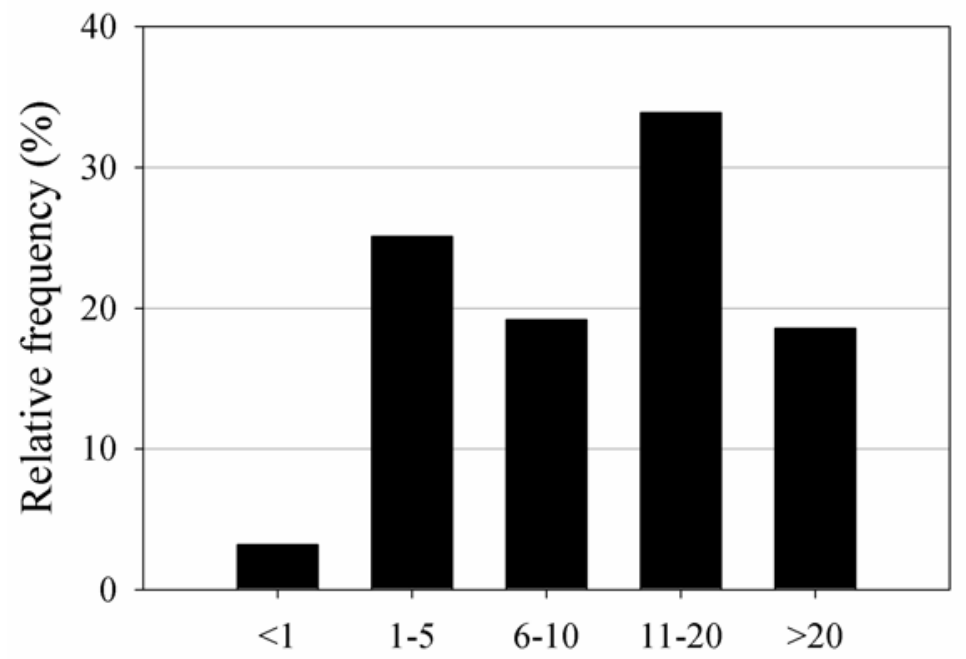

Annual production volume $\left(\mathrm{m}^{3}\right.$ solid wood)

Fig. 2 - The distribution of households over annual volume ( $\mathrm{m}^{3}$ solid wood) of produced firewood $(\mathrm{n}=593)$

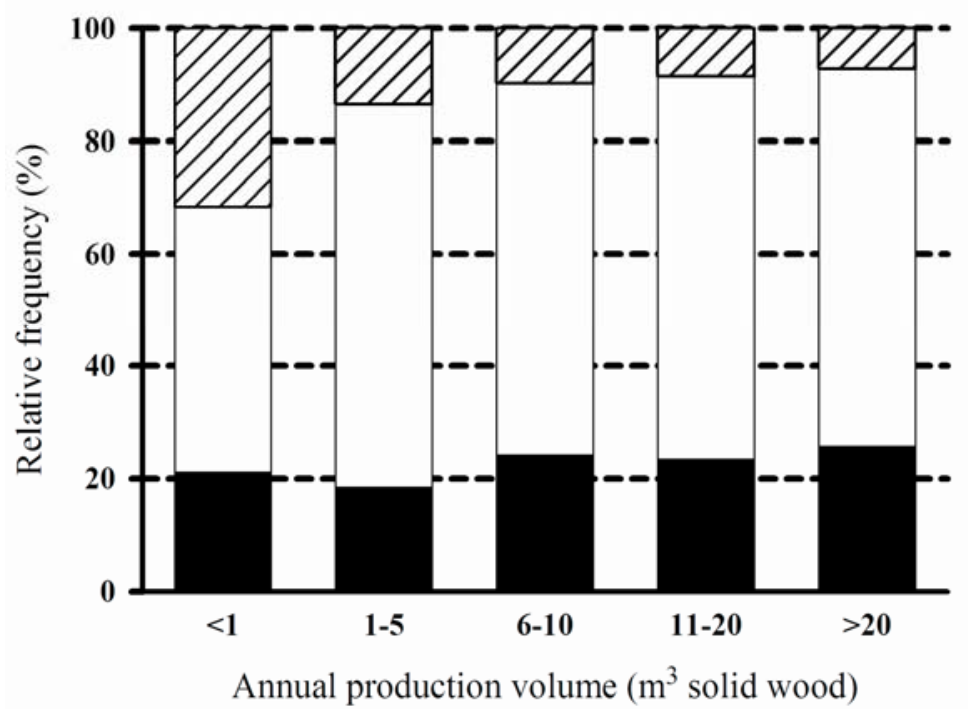

Fig. 3 - The households' reported future production changes (black=decrease, white=no change, slanting lines=increase) distributed over the present annual production volume ( $\mathrm{m}^{3}$ solid wood). 